\title{
PELATIHAN PEMBUATAN VIDEO MENGGUNAKAN KINEMASTER DI SMK ROBBI RODLIYYA
}

\author{
Amran Yobioktabera ${ }^{1}$, Muhammad Irwan Yanwari ${ }^{2}$, Sirli Fahriah ${ }^{3}$, Wiktasari ${ }^{4}$, Aisyatul \\ Karima $^{5}$, Bagus Yunanto ${ }^{6}$, Tahan Prahara ${ }^{7}$, Efrilia Marifatul Khusna ${ }^{8}$, Achmad Fahrul Aji ${ }^{9}$ \\ ${ }^{1,3,5)}$ Program Studi Teknik Informatika, Jurusan Teknik Elektro, Politeknik Negeri Semarang \\ ${ }^{2,4)}$ Program Studi Teknologi Rekayasa Komputer, Jurusan Teknik Elektro, Politeknik Negeri Semarang \\ ${ }^{6,9)}$ Program Studi Teknik Elektronika, Jurusan Teknik Elektro, Politeknik Negeri Semarang \\ ${ }^{7,8)}$ Program Studi Teknik Telekomunikasi, Jurusan Teknik Elektro, Politeknik Negeri Semarang \\ e-mail: amranyobi@polines.ac.id, irwan.yanwari@polines.ac.id, sirlifahriah@polines.ac.id, \\ wiktasari@polines.ac.id, aisya.karima@polines.ac.id, tahanprahara@gmail.com, bagusy@polines.ac.id, \\ Efriliamk@polines.ac.id, achmad.fahrulaji@polines.ac.id
}

\begin{abstract}
Abstrak
Seiring dengan perkembangan teknologi, pengembangan konten video sebagai sebuah bidang pekerjaan menjadi salah satu bidang yang memiliki potensi dalam menyerap tenaga kerja yang belum teralokasikan. Setiap bidang kerja tentunya memerlukan kompetensi yang sesuai dengan bidang yang dituju. Untuk mendukung bidang kerja pengembangan konten video tentunya diperlukan pelatihan dalam pembuatan konten video. SMK Robbi Rodliyya merupakan sekolah yang berfokuskan pada bidang multimedia. Bidang yang menjadi fokus pada SMK ini adalah media gambar dimana siswa mendapatkan pengajaran untuk membuat brosur, banner, dan lainnya menggunakan perangkat lunak pengolahan gambar. Hal ini menyebabkan ketika industri berkembang pada bidang konten video kesulitan dalam penyesuaian kemampuan siswa dalam memenuhi tuntutan perkembangan industri, sehingga perlu dilakukan eksplorasi dan pengembangan wawasan pada bidang pembuatan konten video. Metode yang digunakan pada kegiatan ini meliputi pendampingan pelatihan pembuatan video menggunakan Kinemaster yang terdiri dari empat aktivitas yaitu perencanaan, analisis, implementasi dan evaluasi. Luaran dari pengabdian ini berupa (3) teknologi tepat guna; dan (2) jasa. Hasil pengabdian ini mampu membantu meningkatkan kemampuan siswa dalam pembuatan video dengan menggunakan software Kinemaster. Selain itu dengan adanya pelatihan ini akan sangat membantu para siswa mengembangkan pembuatan konten digital terutama dalam proses pembelajaran.
\end{abstract}

Kata kunci: Multimedia, Pembuatan Video, Kinemaster.

\begin{abstract}
The development of video content creation as a field of work is one of several areas with the potential to absorb unallocated labor. Every field of work certainly requires competence in the intended field. Training in video content creation is needed to make sure the video creation worker has decent knowledge in that field. SMK Robbi Rodliyya is a school that focuses on the multimedia field. SMK Robbi Rodliyya excels in the image processing field, where students can make brochures, banners, and leaflets using image processing software. The video content creation field is different from the image processing field. These differences became a bump for students to adjust their abilities to meet the demands of industrial development. It is necessary to explore and develop insights in the field of video content creation. The method used in this activity includes training assistance in making videos using Kinemaster, which consists of four sub-activities, namely planning, analysis, implementation, and evaluation. The output of this service is in the form of (3) appropriate technology; and (2) services. This service will help to improve students' abilities in making videos using the Kinemaster software. In addition, this training will develop students' capability in the video creation field.
\end{abstract}

Keywords: Multimedia, Video Creation, Kinemaster. 


\section{PENDAHULUAN}

Multimedia adalah teknologi yang merupakan kombinasi lebih dari satu media misalkan terdiri dari gambar, suara, video itu sendiri, animasi, tulisan dan lain sebagainya. perpaduan elemenelemen multimedia memiliki tujuan untuk untuk peningkatan pemahaman atau daya ingat akan apa yang disampaikan. Teknologi multimedia merupakan integrasi, keanekaragaman dan interaksi yang yang memungkinkan kita untuk saling berbagi informasi melalui media digital (Abdulrahaman et al., 2020). Video merupakan salah satu media multimedia yang memungkinkan untuk mengekspresikan sesuatu lebih baik dibanding dengan media lainnya. Video sangat powerful dan merupakan hal yang sudah biasa ada dalam kehidupan sehari-hari. Video telah berkembang secara kualitas seiring dengan perkembangan teknologi. Studi menunjukkan bahwa penggunaan video dalam proses pembelajaran dapat memotivasi pendengarnya dan meningkatkan proses mengingat konten materi (Mustofa \& Sari, 2020). Seiring dengan perkembangan teknologi, pengembangan konten video sebagai sebuah bidang pekerjaan menjadi salah satu bidang yang memiliki potensi dalam menyerap tenaga kerja yang belum teralokasikan. Hal ini ditunjukkan dengan meningkatnya perputaran keuangan pada bidang ini mulai dari pembuatan konten hiburan hingga pengembangan video untuk mendorong brand awareness (Febriyantoro, 2020). Setiap bidang kerja tentunya memerlukan kompetensi yang sesuai dengan bidang yang dituju. Untuk mendukung bidang kerja pengembangan konten video tentunya diperlukan pelatihan dalam pembuatan konten video. SMK Robbi Rodliyya merupakan sekolah yang berfokuskan pada bidang multimedia. Bidang yang menjadi fokus pada SMK ini adalah media gambar dimana siswa mendapatkan pengajaran untuk membuat brosur, banner, dan lainnya menggunakan perangkat lunak pengolahan gambar. Hal ini menyebabkan kemampuan dalam pengolahan video menjadi kurang tereksplorasi.

\section{METODE}

Pada metodologi yang digunakan, terdapat empat aktivitas yang dilakukan diantaranya adalah :

1) Perencanaan

Kegiatan ini sangat penting dilakukan untuk mengetahui sarana dan prasarana yang sudah ada serta metode pembelajaran yang sudah dilakukan.

2) Analisis

Berdasarkan hasil perencanaan awal, dilakukan analisis permasalahan mitra, kebutuhan dari mitra dan penyusunan materi yang akan disampaikan.

3) Implementasi

Melaksanakan pelatihan untuk menjawab permasalahan yang dihadapi berdasarkan solusi yang ditawarkan. Metode yang digunakan dalam tahap implementasi berupa penyampaian materi training yang dilakukan dengan metode ceramah, demonstrasi dan studi kasus.

4) Evaluasi

Evaluasi dilakukan untuk mengetahui hasil dari pengimplementasian solusi.

\section{HASIL DAN PEMBAHASAN}

Dalam tahapan perencanaan, dilaksanakan kegiatan survei ke lokasi pengabdian SMK Robbi Rodliyya yang terletak di Jl. Wolter Monginsidi No.59, Genuk, Kota Semarang. Adapun kegiatan ini dilaksanakan dengan mengunjungi laboratorium komputer untuk mendapatkan gambaran kapasitas ruangan dan tanya jawab terkait kurikulum bidang multimedia pada SMK Robbi Rodliyya 


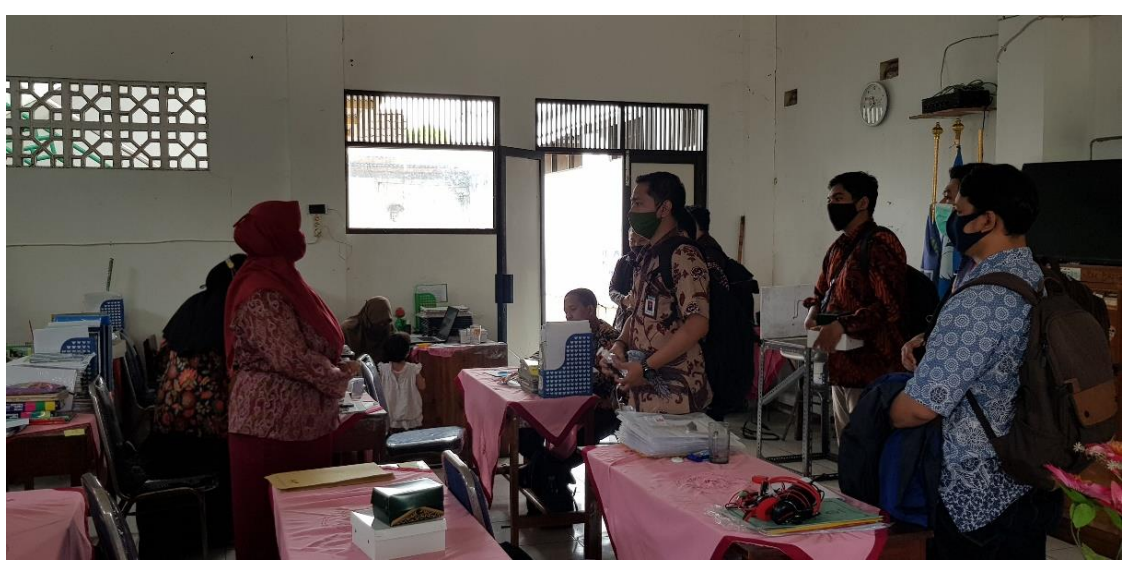

Gambar 1. Survei lapangan pada tahap perencanaan

Berdasarkan hasil perencanaan awal, ditemukan permasalahan dimana hingga saat ini fokus bidang multimedia yang ditekuni oleh tenaga pengajar dan siswa adalah bidang konten gambar, sehingga ketika industri berkembang pada bidang konten video, hal ini menyebabkan sulitnya penyesuaian kemampuan siswa dalam memenuhi tuntutan perkembangan industri. Menggunakan permasalahan tersebut sebagai akar yang akan diselesaikan, didapatkan kesimpulan bahwa perlunya dilakukan pelatihan untuk menjawab permasalahan yang dihadapi. Pelatihan ditujukan untuk memberikan pengetahuan dasar mengenai pembuatan konten video dan mendorong peserta untuk mengeksplorasi industri video yang saat ini sedang booming. Konten video dapat dikembangkan menggunakan berbagai cara dan perangkat. Dalam menentukan materi yang akan disampaikan, tim pengabdian memutuskan menggunakan perangkat lunak kinemaster. Pengambilan keputusan tersebut dilakukan karena kinemaster merupakan salah satu perangkat lunak yang populer untuk pembuatan konten video.

Dalam melaksanakan pelatihan yang telah direncanakan, tim pengabdian memutuskan untuk menggunakan fasilitas yang ada pada SMK Robbi Rodliyya. Peserta pada pelatihan ini adalah tenaga pengajar dan siswa SMK Robbi Rodliyya.

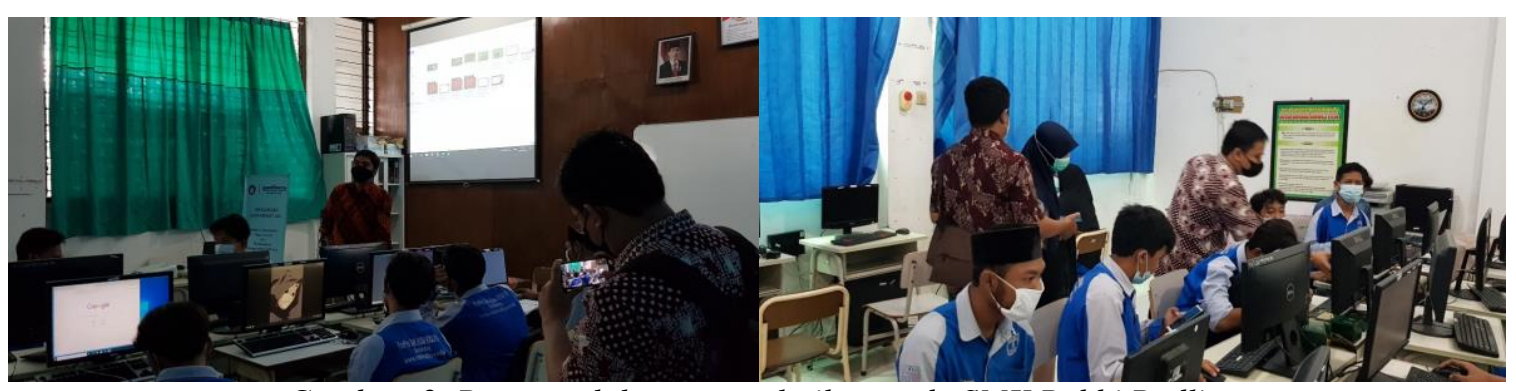

Gambar 2. Proses pelaksanaan pelatihan pada SMK Robbi Rodliyya

Evaluasi dilakukan dengan melihat hasil pembuatan konten video oleh peserta. Konten video hasil buatan peserta dinilai oleh tim pengabdian berdasarkan kriteria berikut

1. Kejelasan informasi yang disampailkan pada video

2. Kejelasan suara pada video

3. Penggunaan metode yang disampaikan pada proses pembuatan video

Berdasarkan hasil penilaian yang dilakukan, peserta pelatihan memiliki kemampuan yang cukup untuk membuat konten video. Berdasarkan hasil survei yang dilakukan setelah pelatihan berakhir, didapatkan kesimpulan bahwa peserta merasa terbantu dalam mengeksplorasi bidang multimedia khususnya pada bidang konten video (dari 11 peserta yang mengikuti pelatihan, 11 peserta menyatakan puas dengan pelatihan yang diberikan). 


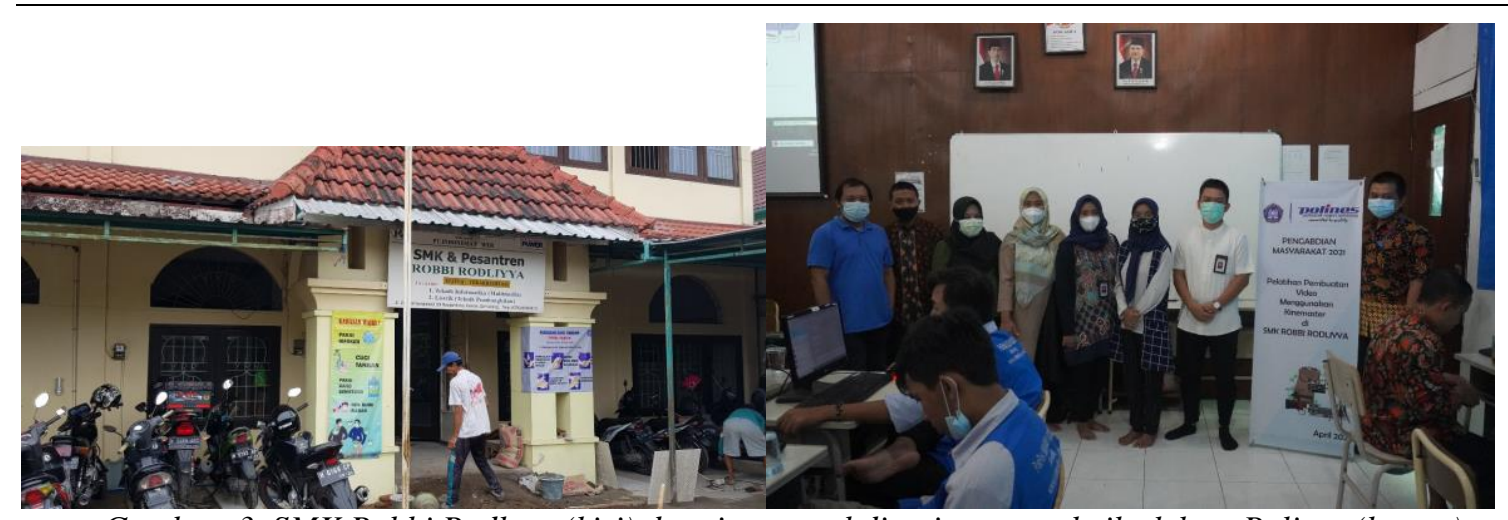

Gambar 3. SMK Robbi Rodlyya (kiri) dan tim pengabdian jurusan teknik elektro Polines (kanan)

\section{SIMPULAN}

Berdasarkan kegiatan pengabdian yang telah dilakukan dapat disimpulkan bahwa peserta mampu mengimplementasikan langkah-langkah pembuatan konten video. Hal ini dibuktikan dengan langkah-langkah pembuatan video yang dilakukan oleh peserta sesuai dengan prosedur yang diharapkan. Selain itu peserta mampu membuat video sederhana menggunakan Kinemaster dimana informasi yang ada pada video tersampaikan secara jelas. Dalam pengabdian ini peserta merasa terbantu dalam mengeksplorasi bidang multimedia khususnya pada bidang konten video yang mana hal ini dibuktikan dengan hasil survei peserta pasca pelatihan.

\section{SARAN}

Berdasarkan hasil yang didapatkan pada pengabdian ini, tim pengabdian menyarankan agar pengembangan pelatihan ini selanjutnya dapat dikembangkan ke pembentukan kelas dan diskusi digital. Sehingga lebih dari sekedar berbagi materi, guru dan siswa dapat berinteraksi secara online. Selain itu Karena fasilitas yang dimiliki setiap peserta berbeda-beda (laptop, komputer, dan smartphone), perlu dilakukan pelatihan lainnya yang sesuai dengan fasilitas yang dimiliki peserta.

\section{UCAPAN TERIMA KASIH}

Ucapan terima kasih tidak lupa diucapkan oleh penulis kepada :

1. Yusnan Badruzzaman, S.T., M.Eng., selaku Ketua Jurusan Teknik Elektro Politeknik Negeri Semarang yang telah membantu dan memberikan ijin kepada tim pengabdian untuk melaksanakan pengabdian kepada masyarakat.

2. Jajaran staf Jurusan Teknik Elektro Politeknik Negeri Semarang yang telah membantu dan berkerjasama selama pelaksanaan pengabdian kepada masyarakat.

3. Faqihhuddin Habibullah Al Ihsani, S.Sos., S.Kom., M.Si., selaku Kepala Sekolah SMK Robbi Rodliyya yang telah membantu dan mengijinkan tim pengabdian dalam melaksanakan kegiatan pengabdian kepada masyarakat.

4. Jajaran staf SMK Robbi Rodliyya yang telah membantu dan berkerjasama selama pelaksanaan pengabdian kepada masyarakat.

5. Tim pengabdian masyarakat Jurusan Teknik Elektro Politeknik Negeri Semarang yang telah memberikan dukungan baik berupa tenaga dan finansial selama pelaksanaan pengabdian kepada masyarakat.

\section{DAFTAR PUSTAKA}

Abdulrahaman, M. D., Faruk, N., Oloyede, A. A., Surajudeen-bakinde, N. T., \& Olawoyin, L. A. (2020). Multimedia tools in the teaching and learning processes: A systematic review. Heliyon, 6(February), e05312. https://doi.org/10.1016/j.heliyon.2020.e05312

Febriyantoro, M. T. (2020). Exploring YouTube Marketing Communication: Brand awareness, brand image and purchase intention in the millennial generation. Cogent Business and Management, 7(1). https://doi.org/10.1080/23311975.2020.1787733

Mustofa, M., \& Sari, A. S. (2020). Video subtitle to teach listening skill of junior high school students. JEES (Journal of English Educators Society), 5(2), 149-153. https://doi.org/10.21070/jees.v5i2.874 